\title{
Differential expression of miRNAs related to angiogenesis and adipogenesis in subcutaneous fat of obese and nonobese women
}

\author{
Aline S. Gasparotto ${ }^{1}$ (1) - Diego O. Borges ${ }^{1} \cdot$ Marina G. M. Sassi $^{1} \cdot$ Adriana Milani $^{2} \cdot$ Darwin L. Rech $^{2} \cdot$ Marcia Terres $^{2}$. \\ Pedro B. Ely ${ }^{2} \cdot$ Mauricio J. Ramos ${ }^{3} \cdot$ Nelson G. Meihnardt $^{3} \cdot$ Vanessa S. Mattevi $^{1}$
}

Received: 18 July 2018 / Accepted: 4 December 2018 / Published online: 18 December 2018

(c) Springer Nature B.V. 2018

\begin{abstract}
To disclose the mechanisms surrounding obesity, we selected microRNAs (miRNAs) that target genes involved in adipogenesis, angiogenesis, and inflammation and compared their expression levels in the subcutaneous adipose tissue of 40 obese and nonobese women. Mature miRNAs were extracted from subcutaneous adipose tissue samples that were collected during surgery and quantified by real-time polymerase chain reaction. miR-16 was overexpressed in the nonobese group (n-expression ratio $=-151.1 ; \mathrm{P}<0.001)$. Furthermore, the expression levels of two other miRNAs were significantly correlated with waist circumference in nonobese women (miR-27b, $r=0.453 ; \mathrm{P}=0.027$ and miR-424-5p, $\mathrm{r}=0.502, \mathrm{P}=0.014)$. Central and total subcutaneous adipose tissue thicknesses were correlated with miR-424-5p levels $(r=0.506, P=0.034$ and $r=0.475$, $\mathrm{P}=0.046$, respectively) in the nonobese group. In the obese group, miR-424-5p expression was correlated with body mass index $(\mathrm{r}=0.582, \mathrm{P}=0.018)$. miR-16 and miR-424 have shown correlations with body-fat-mass-related parameters. Because these miRNAs have vascular endothelial growth factor (VEGF) and its receptors as target genes, they may be involved in the alterations of angiogenesis observed in obesity. In addition, higher levels of miR-27 and miR-424 were correlated with higher fat depot measurements in nonobese women. These results highlight the importance of miRNA expression in subcutaneous adipose tissue and encourage further investigation of miRNAs as prognostic markers.
\end{abstract}

Keywords Adipose tissue $\cdot$ Obesity $\cdot$ microRNA $\cdot \operatorname{miR}-16 \cdot \operatorname{miR}-424 \cdot \operatorname{miR}-27$

An abstract of this work was presented at the 24th European Congress on Obesity (ECO2017, Portugal; Obes Facts 2017;10(suppl 1):1-274 https://doi.org/10.1159/000468958).

Aline S. Gasparotto

lila.gasparotto@gmail.com; lila_sg@ufcspa.edu.br

Diego O. Borges

diego.borges@fcm.unl.pt

Marina G. M. Sassi

marina.sassi@santacasa.tche.br

Adriana Milani

adriana.milani@santacasa.tche.br

Darwin L. Rech

darwin.rech@santacasa.tche.br

Marcia Terres

marcia.terres@santacasa.tche.br

Pedro B. Ely

pedro.ely@santacasa.tche.br

Mauricio J. Ramos

mauricioramos@ghc.com.br
Nelson G. Meihnardt

nelsonmeinhardt@ghc.com.br

Vanessa S. Mattevi

vmattevi@ufcspa.edu.br

1 Programa de Pós-graduação em Ciências da Saúde, Universidade Federal de Ciências da Saúde de Porto Alegre, Rua Sarmento Leite, 245 - Centro Histórico, Porto Alegre, RS 90050-170, Brazil

2 Irmandade Santa Casa de Misericórdia de Porto Alegre, Rua Professor Annes Dias, 295 - Centro Histórico, Porto Alegre, RS 90020-090, Brazil

3 Hospital Nossa Senhora da Conceição, Avenida Francisco Trein, 596 - Cristo Redentor, Porto Alegre, RS 91350-200, Brazil 


\section{Introduction}

Obesity and its related comorbidities, such as type II diabetes, cardiovascular diseases, and certain types of cancer, have been threatening the health of a growing number of people worldwide [1]. To fight this global epidemic, the study of adipose tissue biology has become increasingly important in recent years.

Evidence has accumulated indicating that obesity is associated with a state of adipose tissue remodeling characterized by adipocyte hypertrophy, increased angiogenesis and the production of proinflammatory adipokines during the progression of chronic inflammation [2, 3]. Unbalanced production of regulatory molecules by adipocytes, macrophages and endothelial cells may play a major role in this pathology.

A new component of post-transcriptional control of gene expression, performed by microRNAs (miRNAs), has been discovered, which has been related to most biological processes, including adipose tissue functionality $[4,5]$. The importance of miRNAs is well recognized in regulating genetic networks and subsequent physiological processes. Altered expression levels of miRNAs in human and animal models have been associated with various disease conditions and their progression, including obesity-associated comorbidities [6-8]. miRNAs can suppress the production of target proteins by inducing the degradation of their messenger RNA (mRNA) and/or blocking their translation [9] by binding to the $3^{\prime}$ untranslated region of mRNAs.

Although it is widely accepted that obesity is a heritable condition, even the most powerful genome-wide association study (GWAS) published [10] has so far explained only $2.7 \%$ of the variation in body mass index in the general population. Furthermore, Shungin et al. [11] conducted a genome-wide association meta-analysis of traits related to waist and hip circumferences in up to 224,459 individuals, finding that the pathway analyses implicated adipogenesis, angiogenesis, transcriptional regulation and insulin resistance as processes affecting fat distribution. Thus, the explanation of this so-called "missing heritability" in adiposity may rely on the less-explored level of gene regulation at the level of miRNA expression. Furthermore, several miRNAs and their targets have been implicated in the linkage between inflammation, angiogenesis and obesity $[8,12,13]$ in the years since their discovery.

Considering this evidence, we hypothesized and aimed to determine whether specific miRNAs targeting genes involved in angiogenesis, inflammation, and adipogenesis may be differentially expressed in adipose tissue from obese and nonobese individuals. We believe this determination can improve the understanding of the molecular mechanisms underlying the accumulation of fat mass in the human body.

\section{Materials and methods}

\section{Study population}

This cross-sectional study included 40 women who were consecutively recruited from reference centers in two hospitals in Porto Alegre in southern Brazil. The obese group (body mass index, BMI $\geq 30 \mathrm{~kg} / \mathrm{m}^{2}$ ) consisted of 20 patients who underwent bariatric surgery for weight management and one who underwent cosmetic surgery (a total of 21 individuals). On the other hand, the nonobese group $\left(\mathrm{BMI}<30 \mathrm{~kg} / \mathrm{m}^{2}\right)$ consisted of 19 patients who underwent abdominoplasty for cosmetic purposes.

The inclusion criteria for the study were patients older than 18 years of age and who had a confirmed BMI according to the group to which they belonged at the moment of enrollment. The exclusion criteria were pregnancy and chronic inflammatory diseases.

\section{Procedures}

An interview was performed at enrollment to obtain demographic and lifestyle information. The patients' ethnicities were self-defined and classified as white or nonwhite (black and brown). Subcutaneous adipose tissue and plasma samples were obtained from all patients during surgery.

\section{Anthropometric analysis}

At the moment of inclusion in the study, for nonobese patients, a complete physical examination, including measurements of weight (kilograms), height (meters), waist circumference (centimeters) and seven skinfold thicknesses (millimeters), was performed by the same researcher. The skinfold thickness measurements were performed in triplicate on the right side of the body with a Lange skinfold caliper (Beta Technology, California, USA). Biceps, triceps and calf folds were grouped into a single measurement referred to as limb subcutaneous fat (LSF). Subscapular, axillary, suprailiac and abdominal folds were grouped into a single measurement referred to as central subcutaneous fat (CSF). Total subcutaneous fat (TSF) was calculated as the total sum of LSF and CSF. BMI was calculated using the following formula: $\mathrm{BMI}=$ weight in kilograms/(height in meters) ${ }^{2}$. All data were stored in a database using the Microsoft Excel program (Microsoft Corporation, Redmond, Washington, USA). For obese patients, only BMI was assessed because the data in the literature suggest that waist circumference and skinfold 
thickness in extremely obese patients are imprecise, and no additional clinically distinguishing or relevant information would likely be obtained by performing anthropometric assessments other than BMI in these individuals [14, 15].

\section{microRNA selection}

A total of 11 miRNAs were chosen based on their complementarity to the $3^{\prime}$ UTR regions of target genes involved in metabolic, angiogenic and inflammatory adipose pathways (Table 1). miRNAs that target our genes of interest were selected through the TargetScanHuman [16] and confirmed by miRBase [17] and miRò online databases [18]. From all miRNAs listed by the database for each gene of interest, we selected only those that showed an exact match of the mature miRNA to positions $2-8$.

\section{microRNA collection and analysis}

Subcutaneous adipose tissue samples were collected from the region near the stomach by the surgeon during the procedure and were immediately stored in $1 \mathrm{~mL}$ of Allprotect tissue reagent ${ }^{\circledR}$ (Qiagen, Hilden, Germany) at $-20{ }^{\circ} \mathrm{C}$. Approximately $100 \mu \mathrm{g}$ of tissue was ground in $1 \mathrm{~mL}$ of the homogenization denaturing lysis buffer from mirVana miRNA Isolation Kit ${ }^{\circledR}$ (Life Technologies, California, USA) using a Turrax tissue homogenizer (Marconi, São Paulo, Brazil). Then, the samples were subjected to acidphenol:chloroform extraction. Homogenate was then subjected to the mirVana miRNA Isolation Kit ${ }^{\circledR}$ protocol for total RNA isolation. Ethanol was added to the samples, and they were passed through a filter cartridge containing a glass-fiber filter. Then, the filter was washed a few times, and total RNA was eluted with a low ionic-strength solution. After sequential filtrations with different ethanol concentrations, an RNA fraction highly enriched in RNA species $\leq 200$ nucleotides was obtained and stored at $-80{ }^{\circ} \mathrm{C}$. RNA integrity and quantification were measured with BioSpec-nano (Shimadzu ${ }^{\circledR}$, Kyoto, Japan). microRNAs were enriched to a final concentration of $1.2 \mathrm{ng} / \mu \mathrm{L}$ of total RNA eluted through a multiplex approach by using a pool of individual stem-loop primers of selected microRNA assays (Life Technologies ${ }^{\circledR}$, California, USA). Subsequently, the TaqMan ${ }^{\circledR}$ microRNA Reverse Transcription Kit (Life Technologies ${ }^{\circledR}$, California, USA) was used with a preamplification step. All cDNAs were stored at freezer temperature for no longer than 5 days. Afterwards, preamplified mature microRNAs from each sample were used in duplicate for relative quantification in a StepOnePlus ${ }^{\mathrm{TM}}$ real-time PCR System (Life Technologies $®$, California, USA) using hydrolysis probes for detection and following the MIQE guidelines [35]. Samples from both groups were included in each batch to avoid any measurement bias.

An automatic baseline combined with a global threshold of 0.09 was used throughout the analysis. miRNA expression was measured using a threshold cycle $\left(\mathrm{C}_{\mathrm{T}}\right)$. Target miRNA $\mathrm{C}_{\mathrm{T}}$ values were normalized to miR-let-7d and miR-126 endogenous controls, which presented the lowest variation among all assays evaluated with ExpressionSuite Software version 1.0.3 (Life Technologies ${ }^{\circledR}$,
Table 1 Selected miRNAs and target genes identified through online databases ${ }^{\mathrm{a}}$ and literature data

\begin{tabular}{|c|c|c|c|}
\hline miRBase ID & Mature miRNA sequence & Predicted target & References \\
\hline hsa-miR-16-5p & UAGCAGCACGUAAAUAUUGGCG & VEGF/VEGFR2 & [19] \\
\hline hsa-miR-26b-5p & UUCAAGUAAUUCAGGAUAGGU & $\begin{array}{l}\text { TNFA/LEPT/RESIST/ } \\
\text { AP2/C/EBP } \alpha / P P A R G / \\
\text { HSL }\end{array}$ & {$[20,21]$} \\
\hline hsa-miR-27a-3p & UUCACAGUGGCUAAGUUCCGC & PPARG/PHB & {$[22-24]$} \\
\hline hsa-miR-27b-3p & UUCACAGUGGCUAAGUUCUGC & PPARG/PHB & {$[24,25]$} \\
\hline hsa-miR-125b-5p & UCCCUGAGACCCUAACUUGUGA & VEGF & {$[26,27]$} \\
\hline hsa-miR-132-3p & UAACAGUCUACAGCCAUGGUCG & SIRT1/CREB & {$[28,29]$} \\
\hline hsa-miR-186-5p & CAAAGAAUUCUCCUUUUGGGCU & CASP10/P2RX7 & {$[30,31]$} \\
\hline hsa-miR-223-3p & UGUCAGUUUGUCAAAUACCCCA & PKNOX1/GLUT4 & {$[32,33]$} \\
\hline hsa-miR-424-3p & CAAAACGUGAGGCGCUGCUAU & VEGF/VEGFR & [19] \\
\hline hsa-miR-424-5p & CAGCAGCAAUUCAUGUUUUGAA & VEGF/VEGFR & [19] \\
\hline hsa-miR-519d-3p & CAAAGUGCCUCCCUUUAGAGUG & PPARG/PPARA & [34] \\
\hline
\end{tabular}

$V E G F$ vascular endothelial growth factor, VEGFR2 vascular endothelial growth factor receptor 2, TNFA tumor necrosis factor alpha, $L E P T$ leptin, RESIST resistin, $A P 2$ adipocyte lipid-binding protein, $C / E B P \alpha$ CCAAT/enhancer binding protein $\alpha, P P A R G$ peroxisome proliferator-activated receptor gamma, $P H B$ prohibitin, $H S L$ hormone-sensitive lipase, SIRT1 sirtuin-1, CREB cAMP responsive element binding protein, CASP10 caspase-10, P2RX7 P2 7 receptor gene, PKNOX1 PBX/knotted 1 homeobox 1, GLUT4 glucose transporter 4, PPARA peroxisome proliferator-activated receptor alpha

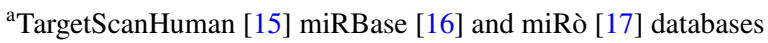


California, USA). RNU48 was also tested as an endogenous control; however, it presented a higher level of variation than the aforementioned miRNAs.

\section{Plasma adipokines}

Human leptin, resistin and adiponectin were profiled in EDTA plasma samples with ELISA kits (EMD Millipore ${ }^{\circledR}$, Darmstadt, Germany). The assays were performed according to the manufacturer's instructions, and the absorbances were read in a Biorad $\AA$ (California, USA) microplate absorbance reader.

\section{Ethical considerations}

All participants were informed about the purposes of the study and signed a free and informed consent form. This study was approved by the Research Ethics Committee of each participating center (protocol numbers 481/11, Irmandade Santa Casa de Misericórdia de Porto Alegre Hospital committee, and 11-105, Nossa Senhora da Conceição Hospital committee).

\section{Statistical analyses}

Using the Winpepi software [36] set to 95\% reliability and $90 \%$ power, we estimated that a sample of at least 38 subjects was necessary to detect a difference in miRNA levels of $10 \%$ between groups.

Demographic and clinical continuous variables were compared between the two groups (obese and nonobese) using Student's t-test for independent samples. Categorical variables were contrasted with the chi-squared test with Yates' continuity correction or Fisher's exact test. Asymmetrically distributed data (BMI, adiponectin and resistin levels) were transformed into their natural logarithm and then used for statistical analyses.

To normalize miRNA data to the internal controls and calculate the expression ratio between groups, the $2^{-\mathrm{dCt}}$ approach [37] was used. Nonparametric groupwise Mann-Whitney U and Student's t-test for independent samples were used to compare miRNA expression between obese and nonobese patients. Additionally, plasma adipokine levels and BMI were correlated with the expression levels of individual miRNAs by using Pearson's or Spearman's statistics. All data were analyzed using the SPSS 17.0 program (SPSS Inc., Chicago, Illinois, USA). All tests were two-sided, and the level of significance was defined as a $\mathrm{P}$ value less than 0.05 .

\section{Results}

All patients were female, and their mean age was $42.0 \pm 11.3$ years. The main characteristics of the total sample stratified by BMI (nonobese and obese) are presented in Table 2 . The majority of the subjects $(95 \%)$ were nonsmokers. Nonobese individuals engaged in physical activity more frequently than obese patients (Table $2, \mathrm{P}=0.011$ ).

All three adipokine plasma levels (leptin, adiponectin, and resistin) were compared between obese and nonobese individuals and are also shown in Table 2. Plasma levels of leptin $(\mathrm{P}<0.001)$ and adiponectin $(\mathrm{P}=0.039)$ were higher and lower in obese subjects, respectively. In contrast, resistin plasma levels were not different between groups. In the nonobese group, leptin plasma levels were significantly correlated with waist circumference $(\mathrm{r}=0.496, \mathrm{P}=0.036)$. However, adiponectin and resistin levels were not correlated with waist circumference $(\mathrm{r}=0.240, \mathrm{P}=0.924$ and $\mathrm{r}=0.295$, $\mathrm{P}=0.235$, respectively).

Table 2 Biodemographic characteristics of the studied samples

\begin{tabular}{|c|c|c|c|}
\hline \multirow[t]{2}{*}{ Characteristic } & \multicolumn{2}{|l|}{ Group } & \multirow[t]{2}{*}{$\mathrm{P}$ value } \\
\hline & Nonobese $(\mathrm{N}=19)$ & Obese $(\mathrm{N}=21)$ & \\
\hline \multicolumn{4}{|l|}{ Demographic } \\
\hline Age (years) & $41.1 \pm 12.9$ & $42.8 \pm 9.9$ & $0.641^{\mathrm{a}}$ \\
\hline \multicolumn{4}{|l|}{ Clinical } \\
\hline BMI $\left(\mathrm{kg} / \mathrm{m}^{2}\right)^{\mathrm{e}}$ & $\begin{array}{l}23.7 \pm 1.7 \\
{[21.2-27.4]}\end{array}$ & $\begin{array}{l}49.3 \pm 10.2 \\
{[33.0-73.0]}\end{array}$ & $<0.001^{\mathrm{a}}$ \\
\hline Weight (kg) & $60.5 \pm 5.4$ & $123.9 \pm 24.0$ & $<0.001^{\mathrm{a}}$ \\
\hline Leptin (ng/dL) & $4.4 \pm 2.6$ & $38.1 \pm 18.6$ & $<0.001^{\mathrm{a}}$ \\
\hline $\begin{array}{l}\text { Adiponectin }(\mu \mathrm{g} / \\
\mathrm{dL})^{\text {de }}\end{array}$ & $23.2 \pm 8.7$ & $18.0 \pm 7.9$ & $0.039^{\mathrm{a}}$ \\
\hline Resistin $(\mathrm{ng} / \mathrm{dL})^{\mathrm{e}}$ & $0.6 \pm 0.2$ & $0.5 \pm 0.2$ & $0.272^{\mathrm{a}}$ \\
\hline Diabetes $^{\mathrm{f}}$ & NA & $11(55 \%)$ & \\
\hline Dyslipidemia $^{\mathrm{f}}$ & NA & $12(60 \%)$ & \\
\hline Hypertension $^{\mathrm{f}}$ & NA & $16(80 \%)$ & \\
\hline \multicolumn{4}{|l|}{ Physical activity ${ }^{\mathrm{g}}$} \\
\hline Yes & $14(73.68 \%)$ & $6(28.57 \%)$ & $0.011^{\mathrm{b}}$ \\
\hline No & $5(26.32 \%)$ & $15(71.43 \%)$ & \\
\hline \multicolumn{4}{|l|}{ Smoking } \\
\hline Yes & 0 & $2(9.52 \%)$ & $0.488^{\mathrm{c}}$ \\
\hline No & $19(100 \%)$ & $19(90.48 \%)$ & \\
\hline
\end{tabular}

$B M I$ body mass index [minimum-maximum], $N A$ not available

${ }^{\text {a}}$ Student's $t$ test for independent samples.

' $\chi^{2}$ test with Yates' correction

${ }^{\mathrm{c}}$ Fisher's exact test

${ }^{\mathrm{d}}$ Test performed without outlier individual no 143 (obese group)

${ }^{\mathrm{e}}$ Variable transformed into $\mathrm{ln}$

${ }^{\mathrm{f}}$ Prevalence data available only for twenty obese individuals

${ }^{\mathrm{g}}$ At least one hour/twice a week 
The differential expression of each miRNA in the two groups analyzed is shown in Table 3. The most striking difference observed was in miR-16, whose expression level was approximately 150 times higher in the subcutaneous adipose tissue of nonobese than in that of the obese group (n-expression ratio $=-151.121 ; \mathrm{P}<0.001)$, which is depicted in Fig. 1. A nonobese outlier individual was excluded from this analysis for showing a $2^{-\mathrm{dCt}}$ value for miR-16 higher than 109.00. No significant differences were observed for the other miRNAs investigated between obese and nonobese women.

We next evaluated the correlation of the studied miRNA expression with the measurements of central and subcutaneous adiposity of the nonobese women, i.e., waist circumference, total subcutaneous fat and central subcutaneous fat. Significant results are presented in Fig. 2. The expression of miR-27b was correlated with waist circumference $(\mathrm{r}=0.576 \mathrm{P}=0.016)$. After adjusting for BMI, this correlation remained significant $(r=0.453 ; P=0.027)$. miR-424-5p was also significantly correlated with waist circumference $(\mathrm{r}=0.562, \mathrm{P}=0.019)$, even after adjusting for BMI $(0.502$, $\mathrm{P}=0.014)$. In addition, miR-424-5p levels were correlated with both TSF and CSF $(r=0.512, P=0.036$ and $r=0.538$, $\mathrm{P}=0.026$, respectively), even after adjusting for BMI $(r=0.475, P=0.046$ and $r=0.506, P=0.034$, respectively). Furthermore, miR-424-3p was correlated with BMI values in the obese group $(\mathrm{r}=0.582, \mathrm{P}=0.018)$. We did not find any significant association regarding the limb subcutaneous fat (LSF) measurement.

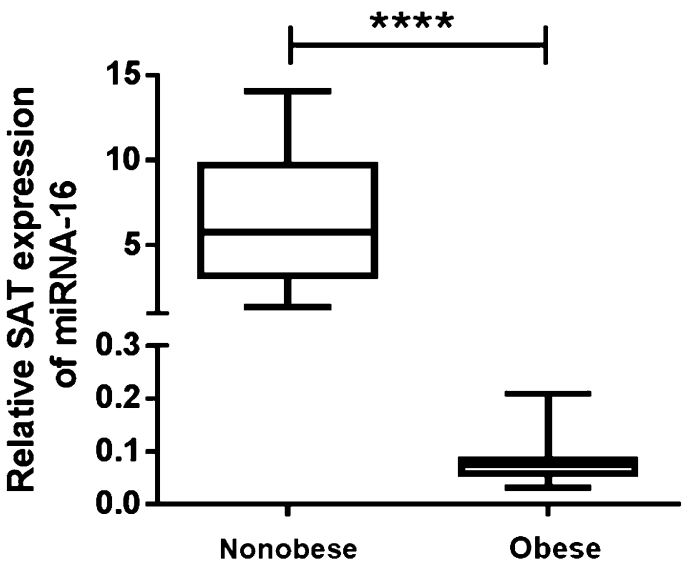

Fig. 1 Comparison of hsa-miR-16-5p expression between obese and nonobese women. Created by GraphPad Prism 5. ****Difference between groups, $\mathrm{n}$-expression ratio $=-151.121 ; \mathrm{P}<0.001$

\section{Discussion}

The metabolic activity of adipose tissue has become a major focus of research due to the worldwide pandemic of obesity. In the present study, we compared the expression of selected miRNAs in subcutaneous fat between a group of obese women and a group of nonobese women to identify differences in the levels of miRNAs that target genes involved in angiogenesis, adipogenesis and inflammation between these two groups.

Table 3 Expression of analyzed miRNAs in obese and nonobese women

\begin{tabular}{|c|c|c|c|c|c|c|}
\hline \multirow[t]{2}{*}{ microRNA } & \multicolumn{2}{|l|}{ Nonobese } & \multicolumn{2}{|l|}{ Obese } & \multirow{2}{*}{$\begin{array}{l}\text { Fold change } \\
\text { obese/non- } \\
\text { obese }\end{array}$} & \multirow[t]{2}{*}{$P$ value } \\
\hline & Mean \pm SD & Median [quartiles] & Mean \pm SD & Median [quartiles] & & \\
\hline hsa-miR-16-5p & $12.21 \pm 23.86$ & $6.02[3.23-10.21]$ & $0.08 \pm 0.04$ & $0.08[0.06-0.08]$ & -151.121 & $<0.001^{\mathrm{a}}$ \\
\hline hsa-miR-26b-5p & $0.28 \pm 0.18(18)$ & $0.36[0.11-0.43](18)$ & $0.35 \pm 0.36$ & $0.32[0.17-0.38]$ & 1.257 & $0.933^{\mathrm{a}}$ \\
\hline hsa-miR-27a-3p & $0.07 \pm 0.05$ & $0.08[0.01-0.11]$ & $0.15 \pm 0.33$ & $0.08[0.03-0.12]$ & 2.074 & $0.616^{\mathrm{a}}$ \\
\hline hsa-miR-27b-3p & $0.07 \pm 0.05$ & $*$ & $0.06 \pm 0.04$ & $*$ & -1.148 & $0.578^{\mathrm{b}}$ \\
\hline hsa-miR-125b-5p & $0.43 \pm 0.37$ & $0.43[0.16-0.51]$ & $0.44 \pm 0.39$ & $0.45[0.20-0.49]$ & 1.025 & $0.860^{\mathrm{a}}$ \\
\hline hsa-miR-132-3p & $0.08 \pm 0.06$ & $*$ & $0.09 \pm 0.05$ & $*$ & 1.164 & $0.929^{b}$ \\
\hline hsa-miR-186-5p & $0.24 \pm 0.14(17)$ & $0.22[0.15-0.33](17)$ & $0.27 \pm 0.17(19)$ & $0.23[0.18-0.34](19)$ & 1.139 & $0.516^{\mathrm{a}}$ \\
\hline hsa-miR-223-3p & $1.46 \pm 1.22$ & $1.27[0.34-2.24]$ & $2.06 \pm 2.68$ & $1.35[0.67-2.38]$ & 1.41 & $0.636^{\mathrm{a}}$ \\
\hline hsa-miR-424-3p & $0.001 \pm 0.0008$ & $0.001[0.0007-0.015](15)$ & $0.003 \pm 0.007$ & $0.001[0.0005-0.018](18)$ & 2.584 & $0.971^{\mathrm{a}}$ \\
\hline hsa-miR-424-5p & $0.0009 \pm 0.0008$ & $\begin{array}{l}0.0008[0.0003-0.0015] \\
\quad(17)\end{array}$ & $0.001 \pm 0.0009(18)$ & $\begin{array}{l}0.0009[0.0005-0.0013] \\
\quad(18)\end{array}$ & 1.228 & $0.531^{\mathrm{a}}$ \\
\hline hsa-miR-519d-3p & $0.0008 \pm 0.0009(16)$ & $\begin{array}{l}0.0005[0.0001-0.001] \\
\quad(16)\end{array}$ & $0.001 \pm 0.002(20)$ & $\begin{array}{l}0.0007[0.0003-0.002] \\
\quad(20)\end{array}$ & 1.851 & $0.161^{\mathrm{a}}$ \\
\hline
\end{tabular}

Data presented as $2^{-\mathrm{dCt}}$ mean $\pm \mathrm{SD}$ and median [quartiles], when the data deviated significantly from the normal distribution; (number of included individuals presented when different from the total); fold change values where calculated with mean; fold change lower than one have been inverted; ${ }^{a}$ Mann-Whitney U test; ${ }^{b}$ Student's t-test for independent samples; *Median value not shown due to the symmetric distribution of the variable 

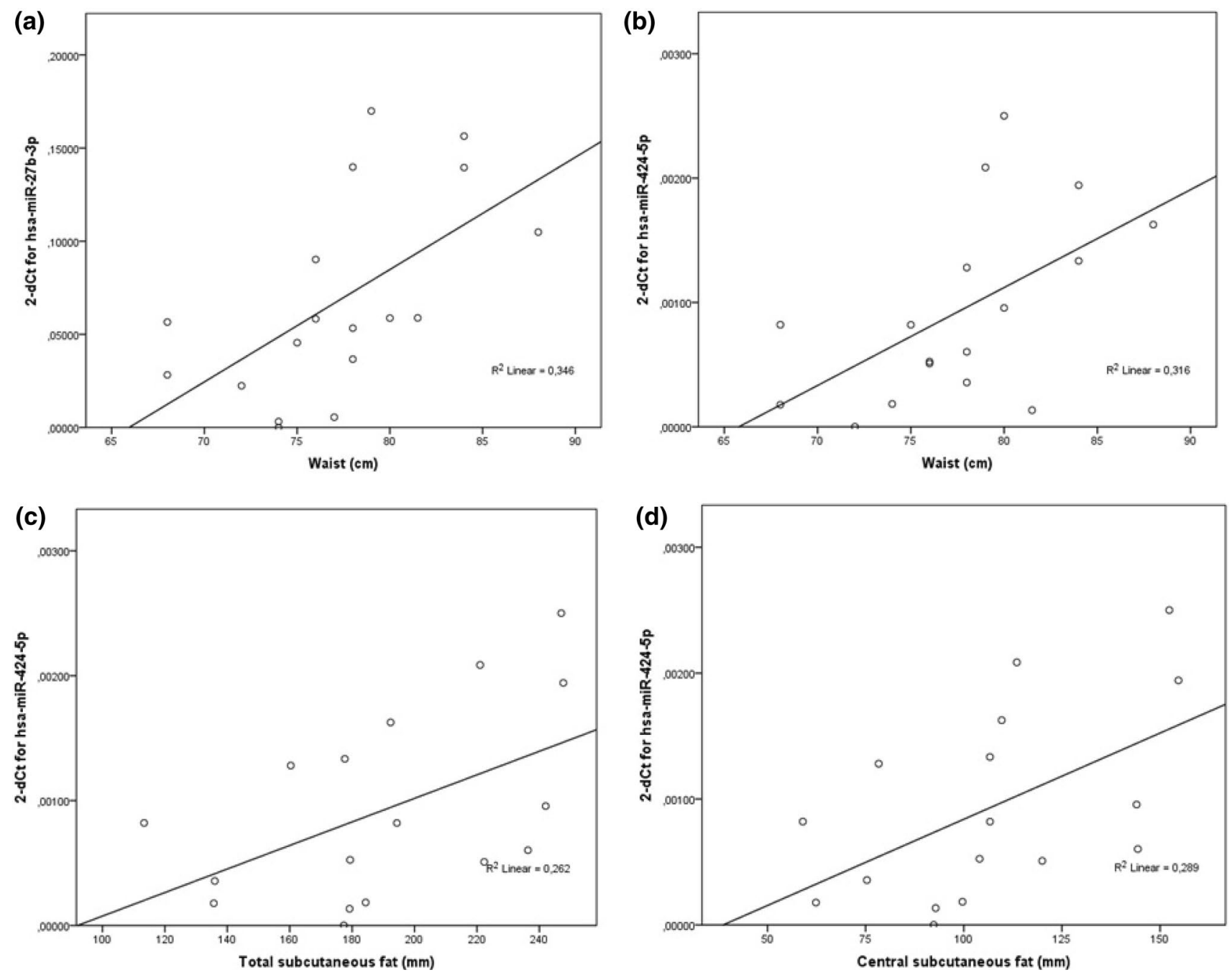

Fig. 2 Significant correlations between miRNAs and anthropometric measures among nonobese women. Created by SPSS program. Nonobese group. a Correlation between expression levels of hsamiR-27b-3p and waist circumference (Pearson's coefficient $=0.576$; $\mathrm{P}=0.016$ ); $\mathbf{b}$ correlation between expression levels of hsa-miR$424-5 \mathrm{p}$ and waist circumference (Pearson's coefficient $=0.562$;

In our sample, miR-16 was significantly overexpressed in the subcutaneous adipose tissue of nonobese compared to the expression in obese women. Elevated levels of a miRNA reduce the translation of its target mRNAs [9]. A previous study [38] computationally and experimentally predicted the vascular endothelial growth factor (VEGF) gene as one of the miR-16 targets, which was also shown in our online databases research (Table 1). Chamorro-Jorganes et al. [39] demonstrated that miR-16 and miR-424 participate in the regulation of VEGF receptor-2 (VEGFR2), fibroblast growth factor-1 (FGFR1) and VEGF genes in vascular endothelial cells in mice. Furthermore, they showed that miR-16 reduces blood vessel formation in vivo. In a review by Holmes et al. [40], VEGF and VEGFR2 genes have been related
$\mathrm{P}=0.019)$; c correlation between expression levels of hsa-miR424-5p and total subcutaneous fat (Pearson's coefficient $=0.512$; $\mathrm{P}=0.036)$; $\mathbf{d}$ correlation between expression levels of hsa-miR424-5p and central subcutaneous fat (Pearson's coefficient $=0.538$; $\mathrm{P}=0.026)$

to the proliferation, migration, survival and permeability of endothelial cells. Additionally, it has been demonstrated that, without correct neovascularization, adipocyte hypertrophy generates a pseudohypoxic state in adipose tissue [41, 42]. Saad et al. [43] demonstrated that some miRNAs, including anti-angiogenic and proapoptotic miRNAs (such as miR-16) in adipose-derived mesenchymal stem/stromal cells, exhibited reduced expression under hypoxic conditions.. Saad et al. also claimed that this group of miRNAs may negatively modulate angiogenesis by repressing $V E G F$ expression under normoxic conditions. Accordingly, overexpression of miR-16 in the subcutaneous fat of nonobese individuals would maintain low expression of the abovementioned proangiogenic target genes, creating an unfavorable 
environment for cell proliferation. As a result, adipogenesis would be impaired in this scenario due to the lack of new vessel formation. Moreover, miR-16 has been described as a suppressor of cell cycle progression by targeting innumerous G1 cyclins [44]. The importance of the $V E G F$ gene has also been highlighted in a recent GWAS [11], which considered it to be one of the components of a gene set with a biological effect on body fat regulation. In a recent review by Elias et al. [45] about the actions of VEGF-A in the control of obesity and insulin resistance in adipose tissue, the authors noted conflicting reports regarding the local and systemic levels of $V E G F$ in obesity. There is evidence showing that $V E G F-A$ concentration in serum correlates significantly with BMI, with higher $V E G F-A$ levels observed in overweight and obese subjects and animal models. However, other authors have failed to reproduce these results, and some studies have reported decreased VEGF-A expression in adipose tissue of obese mice and obese humans.

In contrast with our results, Ortega et al. [46] found elevated levels of miR-16 during adipocyte differentiation in white adipose tissue, suggesting its role in the biogenesis of this tissue. However, many miRNAs have been shown to be upregulated in obesity and downregulated in adipogenesis or vice versa [46, 47]. miR-16 has already been described as an endogenous control in previous studies [28, 48]. However, a comprehensive search for miRNAs to be used as endogenous controls in human adipose tissue performed by Neville et al. [49] did not include miR-16 among the 13 most stable miRNAs found in human adipose tissue.

Despite the fact that both miR-16 and miR-424 share the same seed region, implying similar targets, we did not find statistically significant differences in miR-424 subcutaneous adipose tissue expression between obese and nonobese studied individuals. However, we observed that miR-424 levels were directly correlated with BMI in the obese group and with higher waist, TSF and CSF measurements in the nonobese group. These findings suggest that miR-424 acts in contrast to miR-16 in relation to subcutaneous fat accumulation. In a study by Zhang et al. [50], miR-424 levels were shown to be increased in cancer cells due to a hypoxic microenvironment, leading to apoptotic resistance. Similarly, the greater the adiposity (waist and sum of skinfolds), the higher is the level of hypoxia in white adipose tissue (WAT) and the miR-424 levels due to an excessive adipocyte number sharing the same vascular supply. This evidence led us to speculate that miR-16 and miR-424 have different effects according to the set of genes in each pathway they regulate. Thus, we consider that the final result of miR-424 on the outcome depends on a fine and delicate balance of its duality shown so far: on one side, being overexpressed in hypoxia and, on the other side, acting as an inhibitor of angiogenic factors. Therefore, due to these data, more studies are necessary to explain this duality mentioned.
In relation to miR-27, our results have shown that higher levels of miR-27b in nonobese individuals were correlated with higher waist measurements. Several authors have implicated miR-27b in preadipocyte differentiation [22, $23,25,47]$. Although miR-27b has never been correlated with waist circumference or with any other anthropometric measurement of subcutaneous fat as far as we know, Kang et al. [24] described this miRNA as an inhibitor of adipogenesis. Therefore, by targeting prohibitin $(P H B)$, miR-27 induces downregulation of $P P A R \gamma$ and causes mitochondrial impairment, which leads to a reduction of adipogenesis, as observed in a mouse 3T3-L1 in vitro cell line culture [51]. Moreover, expression of miR-27 has already been related to hypoxia [22], which is increased in obesity. As a result, higher levels of miR-27 are expected to be correlated with higher fat depot measurements, as shown in our analysis.

We are aware that our study presents some limitations. First, our research was performed only in female individuals. However, as emphasized by a recent genome-wide association meta-analysis [11], there is great sexual dimorphism in the genetic regulation of traits related to fat distribution. Moreover, gender is known to influence miRNA expression in human WAT [34]. As a result, having only women enrolled makes our sample more homogeneous, avoiding gender differences and resulting in more robust results. Furthermore, no studies on male individuals focusing on the expression of the miRNAs that we explored were found in the literature, which hampers the ability to compare our results between genders. Another limitation was the lack of other analyses, such as $V E G F$ expression level evaluation, histology and microarray analysis in our sample. However, it is worth noting that a comprehensive analysis of all possible miRNAs expressed in humans is outside the scope of the present study. Furthermore, this study has a significantly higher number of enrolled individuals when compared with other publications on the same topic [28, 34, 46, 52]. Additionally, as far as we know, there are no other studies correlating subcutaneous fat measurements and miRNA expression. As our results were generated from in vivo human tissue and with very sensitive methodologies, we have a more realistic scenario than studies performed with cultured cells and animal models.

In summary, our findings show that miR-16 was highly overexpressed in nonobese WAT and probably acted as an anti-angiogenic factor by binding $V E G F$ and $V E G F R 2$ genes in the sample analyzed. In addition, we found significant correlations of miR-27b and miR-424 expression in subcutaneous adipose tissue with BMI and anthropometric measurements in obese and nonobese women, suggesting that miR-27b and miR-424 play a possible role in modulating body fat distribution but act in a direction opposite to that of miR-16. Furthermore, our data suggest that miR-16 and miR-424 may have opposing effects, and together, they 
may be, at least in part, responsible for the fine-tuning of adipogenesis in adipose tissue. Considering the complex network of miRNA regulation, these results need to be further explored and validated in other studies and with other methodologies. Hence, because the prevalence of obesity poses a heavy clinical burden, innovative strategies to understand the molecular mechanisms that underlie normal and pathophysiological regulation of adipose tissue are needed.

Funding This work has been financially supported by grants from the Conselho Nacional de Desenvolvimento Científico e Tecnológico (CNPq, Brazil - 471437/2012-3) and the Fundação de Amparo à Pesquisa do Estado do Rio Grande do Sul (FAPERGS, Brazil - 12/2226-9 and 1153-2551/13-9). A.S.G. and D.O.B. received scholarships from the REUNI program from Coordenação de Aperfeiçoamento de Pessoal de Nível Superior (CAPES, Brazil).

\section{Compliance with ethical standards}

Conflict of interest The authors declare that they have no conflict of interest.

Ethical approval This study complied with the ethical principles outlined in the Declaration of Helsinki. All enrolled participants were informed and signed informed consent at the beginning of their participation in the study.

\section{References}

1. Ogden CL, Carroll MD, Kit BK, Flegal KM (2014) Prevalence of childhood and adult obesity in the United States, 2011-2012. JAMA 311(8):806-814. https://doi.org/10.1001/jama.2014.732

2. Cao Y (2007) Angiogenesis modulates adipogenesis and obesity. J Clin Invest 117(9):2362-2368

3. Suganami T, Ogawa Y (2010) Adipose tissue macrophages: their role in adipose tissue remodeling. J Leukoc Biol 88(1):33-39

4. Enlund E, Fischer S, Handrick R, Otte K, Debatin KM, Wabitsch M, Fischer-Posovszky P (2014) Establishment of lipofection for studying miRNA function in human adipocytes. PLoS ONE 9(5):e98023. https://doi.org/10.1371/journal.pone.0098023

5. Brandao BB, Guerra BA, Mori MA (2017) Shortcuts to a functional adipose tissue: The role of small non-coding RNAs. Redox Biol 12:82-102. https://doi.org/10.1016/j.redox.2017.01.020

6. Alexander R, Lodish H, Sun L (2011) MicroRNAs in adipogenesis and as therapeutic targets for obesity. Expert Opin Therapeutic Targets 15(5):623-636. https://doi.org/10.1517/14728 222.2011.561317

7. Ono K (2011) MicroRNA links obesity and impaired glucose metabolism. Cell Res 21(6):864-866. https://doi.org/10.1038/ cr.2011.78

8. Chang RC, Ying W, Bazer FW, Zhou B (2014) MicroRNAs control macrophage formation and activation: the inflammatory link between obesity and cardiovascular diseases. Cells 3(3):702-712. https://doi.org/10.3390/cells3030702

9. Guo H, Ingolia NT, Weissman JS, Bartel DP (2010) Mammalian microRNAs predominantly act to decrease target mRNA levels. Nature 466(7308):835-840

10. Locke AE, Kahali B, Berndt SI et al (2015) Genetic studies of body mass index yield new insights for obesity biology. Nature 518(7538):197-206. https://doi.org/10.1038/nature14177
11. Shungin D, Winkler TW, Croteau-Chonka DC et al (2015) New genetic loci link adipose and insulin biology to body fat distribution. Nature 518(7538):187-196. https://doi.org/10.1038/ nature 14132

12. Cao Y (2010) Adipose tissue angiogenesis as a therapeutic target for obesity and metabolic diseases. Nat Rev Drug Discov 9(2):107-115

13. Heneghan HM, Miller N, Kerin MJ (2010) Role of microRNAs in obesity and the metabolic syndrome. Obes Rev 11(5):354 361. https://doi.org/10.1111/j.1467-789X.2009.00659.x

14. Gray DS, Bray GA, Bauer M, Kaplan K, Gemayel N, Wood R, Greenway F, Kirk S (1990) Skinfold thickness measurements in obese subjects. Am J Clin Nutr 51(4):571-577

15. Hastings ES, Anding RH, Middleman AB (2011) Correlation of anthropometric measures among obese and severely obese adolescents and young adults. ICAN: Infant, Child, \& Adolescent Nutrition 3(3):171-174. https://doi.org/10.1177/1941406411 407663

16. TargetScanHuman 6.2. Whitehead Institute for Biomedical Research (2006) Whitehead institute for biomedical research. http://www.targetscan.org/. Accessed 20 April 2013

17. Griffiths-Jones S (2006) miRBase: the microRNA sequence database. Methods Mol Biol 342:129-138. https://doi.org/10.1385/159745-123-1:129

18. Lagana A, Forte S, Giudice A, Arena MR, Puglisi PL, Giugno R, Pulvirenti A, Shasha D, Ferro A (2009) miRo: a miRNA knowledge base. Database 2009:bap008. https://doi.org/10.1093/datab ase/bap008

19. Fiedler J, Thum T (2011) MicroRNAs looping around angiogenesis. Arterioscler Thromb Vasc Biol 31(11):2367-2368. https:// doi.org/10.1161/ATVBAHA.111.237602

20. Xu G, Ji C, Shi C, Fu H, Zhu L, Zhu L, Xu L, Chen L, Feng Y, Zhao Y, Guo X (2013) Modulation of hsa-miR-26b levels following adipokine stimulation. Mol Biol Rep 40(5):3577-3582. https ://doi.org/10.1007/s11033-012-2431-0

21. Song G, Xu G, Ji C, Shi C, Shen Y, Chen L, Zhu L, Yang L, Zhao Y, Guo X (2014) The role of microRNA-26b in human adipocyte differentiation and proliferation. Gene 533(2):481-487. https:// doi.org/10.1016/j.gene.2013.10.011

22. Lin Q, Gao Z, Alarcon RM, Ye J, Yun Z (2009) A role of miR-27 in the regulation of adipogenesis. FEBS J 276(8):2348-2358

23. Kim SY, Kim AY, Lee HW, Son YH, Lee GY, Lee JW, Lee YS, Kim JB (2010) miR-27a is a negative regulator of adipocyte differentiation via suppressing PPARgamma expression. Biochem Biophys Res Commun 392(3):323-328. https://doi.org/10.1016/j. bbrc.2010.01.012

24. Kang T, Lu W, Xu W, Anderson L, Bacanamwo M, Thompson W, Chen YE, Liu D (2013) MicroRNA-27 (miR-27) targets prohibitin and impairs adipocyte differentiation and mitochondrial function in human adipose-derived stem cells. J Biol Chem 288(48):34394-34402. https://doi.org/10.1074/jbc.M113.514372

25. Karbiener M, Fischer C, Nowitsch S, Opriessnig P, Papak C, Ailhaud G, Dani C, Amri EZ, Scheideler M (2009) microRNA miR-27b impairs human adipocyte differentiation and targets PPARgamma. Biochem Biophys Res Commun 390(2):247-251. https://doi.org/10.1016/j.bbrc.2009.09.098

26. Smits M, Wurdinger T, van het Hof B, Drexhage JA, Geerts D, Wesseling P, Noske DP, Vandertop WP, de Vries HE, Reijerkerk A (2012) Myc-associated zinc finger protein (MAZ) is regulated by miR-125b and mediates VEGF-induced angiogenesis in glioblastoma. FASEB J 26(6):2639-2647. https://doi.org/10.1096/ fj. 11-202820

27. He J, Jing Y, Li W, Qian X, Xu Q, Li FS, Liu LZ, Jiang BH, Jiang Y (2013) Roles and mechanism of miR-199a and miR$125 \mathrm{~b}$ in tumor angiogenesis. PLoS ONE 8(2):e56647. https://doi. org/10.1371/journal.pone.0056647 
28. Kloting N, Berthold S, Kovacs P, Schon MR, Fasshauer M, Ruschke K, Stumvoll M, Bluher M (2009) MicroRNA expression in human omental and subcutaneous adipose tissue. PLoS ONE 4(3):e4699

29. Strum JC, Johnson JH, Ward J, Xie H, Feild J, Hester A, Alford A, Waters KM (2009) MicroRNA 132 regulates nutritional stressinduced chemokine production through repression of SirT1. Mol Endocrinol 23(11):1876-1884. https://doi.org/10.1210/ me.2009-0117

30. Zhang J, Du Y, Wu C, Ren X, Ti X, Shi J, Zhao F, Yin H (2010) Curcumin promotes apoptosis in human lung adenocarcinoma cells through miR-186* signaling pathway. Oncol Rep 24(5):1217-1223

31. Zhou L, Qi X, Potashkin JA, Abdul-Karim FW, Gorodeski GI (2008) MicroRNAs miR-186 and miR-150 down-regulate expression of the pro-apoptotic purinergic $\mathrm{P} 2 \times 7$ receptor by activation of instability sites at the 3'-untranslated region of the gene that decrease steady-state levels of the transcript. J Biol Chem 283(42):28274-28286. https://doi.org/10.1074/jbc.M802663200

32. Zhuang G, Meng C, Guo X, Cheruku PS, Shi L, Xu H, Li H, Wang G, Evans AR, Safe S, Wu C, Zhou B (2012) A novel regulator of macrophage activation: miR-223 in obesity-associated adipose tissue inflammation. Circulation 125(23):2892-2903. https://doi. org/10.1161/CIRCULATIONAHA.111.087817

33. Lu H, Buchan RJ, Cook SA (2010) MicroRNA-223 regulates Glut4 expression and cardiomyocyte glucose metabolism. Cardiovasc Res 86(3):410-420. https://doi.org/10.1093/cvr/cvq010

34. Martinelli R, Nardelli C, Pilone V, Buonomo T, Liguori R, Castano I, Buono P, Masone S, Persico G, Forestieri P, Pastore L, Sacchetti L (2010) miR-519d overexpression is associated with human obesity. Obesity (Silver Spring) 18(11):2170-2176

35. Bustin SA, Benes V, Garson JA, Hellemans J, Huggett J, Kubista M, Mueller R, Nolan T, Pfaffl MW, Shipley GL, Vandesompele J, Wittwer CT (2009) The MIQE guidelines: minimum information for publication of quantitative real-time PCR experiments. Clin Chem 55(4):611-622. https://doi.org/10.1373/clinc hem.2008.112797

36. Abramson JH (2011) WINPEPI updated: computer programs for epidemiologists, and their teaching potential. Epidemiol Perspect Innov 8(1):1. https://doi.org/10.1186/1742-5573-8-1

37. Schmittgen TD, Livak KJ (2008) Analyzing real-time PCR data by the comparative C(T) method. Nat Protoc 3(6):1101-1108

38. Hua Z, Lv Q, Ye W, Wong CK, Cai G, Gu D, Ji Y, Zhao C, Wang J, Yang BB, Zhang Y (2006) MiRNA-directed regulation of VEGF and other angiogenic factors under hypoxia. PLoS ONE 1:e116. https://doi.org/10.1371/journal.pone.0000116

39. Chamorro-Jorganes A, Araldi E, Penalva LO, Sandhu D, Fernandez-Hernando C, Suarez Y (2011) MicroRNA-16 and microRNA-424 regulate cell-autonomous angiogenic functions in endothelial cells via targeting vascular endothelial growth factor receptor-2 and fibroblast growth factor receptor-1. Arterioscler Thromb Vasc Biol 31(11):2595-2606. https://doi.org/10.1161/ ATVBAHA.111.236521

40. Holmes K, Roberts OL, Thomas AM, Cross MJ (2007) Vascular endothelial growth factor receptor-2: structure, function, intracellular signalling and therapeutic inhibition. Cell Signal 19(10):2003-2012. https://doi.org/10.1016/j.cellsig.2007.05.013
41. Hubal MJ, Nadler EP, Ferrante SC, Barberio MD, Suh JH, Wang J, Dohm GL, Pories WJ, Mietus-Snyder M, Freishtat RJ (2017) Circulating adipocyte-derived exosomal MicroRNAs associated with decreased insulin resistance after gastric bypass. Obesity (Silver Spring) 25(1):102-110. https://doi.org/10.1002/oby.21709

42. Trayhurn P (2013) Hypoxia and adipose tissue function and dysfunction in obesity. Physiol Rev 93(1):1-21. https://doi. org/10.1152/physrev.00017.2012

43. Saad A, Zhu XY, Herrmann S, Hickson L, Tang H, Dietz AB, van Wijnen AJ, Lerman L, Textor S (2016) Adipose-derived mesenchymal stem cells from patients with atherosclerotic renovascular disease have increased DNA damage and reduced angiogenesis that can be modified by hypoxia. Stem Cell Res Ther 7(1):128. https://doi.org/10.1186/s13287-016-0389-x

44. Bandi N, Zbinden S, Gugger M, Arnold M, Kocher V, Hasan L, Kappeler A, Brunner T, Vassella E (2009) miR-15a and miR-16 are implicated in cell cycle regulation in a Rb-dependent manner and are frequently deleted or down-regulated in non-small cell lung cancer. Cancer Res 69(13):5553-5559. https://doi. org/10.1158/0008-5472.CAN-08-4277

45. Elias I, Franckhauser S, Bosch F (2013) New insights into adipose tissue VEGF-A actions in the control of obesity and insulin resistance. Adipocyte 2(2):109-112. https://doi.org/10.4161/ adip. 22880

46. Ortega FJ, Moreno-Navarrete JM, Pardo G, Sabater M, Hummel M, Ferrer A, Rodriguez-Hermosa JI, Ruiz B, Ricart W, Peral B, Fernandez-Real JM (2010) MiRNA expression profile of human subcutaneous adipose and during adipocyte differentiation. PLoS ONE 5(2):e9022

47. Xie H, Lim B, Lodish HF (2009) MicroRNAs induced during adipogenesis that accelerate fat cell development are downregulated in obesity. Diabetes 58(5):1050-1057. https://doi.org/10.2337/ db08-1299

48. Heneghan HM, Miller N, McAnena OJ, O’Brien T, Kerin MJ (2011) Differential miRNA expression in omental adipose tissue and in the circulation of obese patients identifies novel metabolic biomarkers. J Clin Endocrinol Metab 96(5):E846-E850. https:// doi.org/10.1210/jc.2010-2701

49. Neville MJ, Collins JM, Gloyn AL, McCarthy MI, Karpe F (2011) Comprehensive human adipose tissue mRNA and microRNA endogenous control selection for quantitative real-time-PCR normalization. Obesity (Silver Spring) 19(4):888-892. https://doi. org/10.1038/oby.2010.257

50. Zhang D, Shi Z, Li M, Mi J (2014) Hypoxia-induced miR-424 decreases tumor sensitivity to chemotherapy by inhibiting apoptosis. Cell Death Disease 5:e1301. https://doi.org/10.1038/cddis .2014 .240

51. Liu D, Lin Y, Kang T, Huang B, Xu W, Garcia-Barrio M, Olatinwo M, Matthews R, Chen YE, Thompson WE (2012) Mitochondrial dysfunction and adipogenic reduction by prohibitin silencing in 3T3-L1 cells. PLoS ONE 7(3):e34315. https://doi.org/10.1371/ journal.pone.0034315

52. Estep M, Armistead D, Hossain N, Elarainy H, Goodman Z, Baranova A, Chandhoke V, Younossi ZM (2010) Differential expression of miRNAs in the visceral adipose tissue of patients with non-alcoholic fatty liver disease. Aliment Pharmacol Ther 32(3):487-497 